\title{
Can REDD+ Bring Equitable Benefit to the Marginalized Communities? Insights from Bangladesh
}

\author{
Anar Koli ${ }^{1} \&$ Md. Rakibul Hasan Khan ${ }^{2}$ \\ ${ }^{1}$ Lecturer, Faculty of International Liberal Arts, Soka University, Tokyo, Japan \\ ${ }^{2}$ Assitant Professor, Chauddagram Government College, Comilla, Bangladesh \\ Correspondence: Anar Koli, Faculty of International Liberal Arts, Soka University, 1-236 Tangi Machi, Hachioji \\ Shi, Tokyo 192-8577, Japan. E-mail: koli@soka.ac.jp
}

Received: October 15, 2018

Accepted: November 7, 2018

Online Published: November 18, 2018

doi:10.5539/jsd.v11n6p1

URL: https://doi.org/10.5539/jsd.v11n6p1

\begin{abstract}
Despite promising win-win outcomes of the Reducing Emissions from Deforestation and Forest Degradation $(\mathrm{REDD}+)$ program, how and to what extent it can bring real opportunities to forest communities remains debatable. Focusing on inequality and land tenure insecurity in Bangladesh, this study aims to find out whether and to what extent REDD+ can ensure equitable benefits and opportunities for the forest communities in an ethnic conflict area. Based on qualitative case studies on two types of community forest management (CFM) experiences in Bangladesh, the study finds that the distribution of various costs, benefits, and access to forest participation remain highly unequal among different groups within the communities. The existing institutional settings were not able to bring adequate opportunities for the marginal forest people to face the dominant power relation and bring equitable share for them. This study argues that without ensuring the decision-making space for marginalized groups, and without substantial changes towards the tenure complexity, the emerging REDD+ initiatives in Bangladesh can strengthen the dominant power and subsequently intensify the vulnerability of the marginalized people. A careful analysis of how weak institutions are helping to perpetuate inequality can thus help us to understand future risks of CFM-REDD+ relations.
\end{abstract}

Keywords: REDD+, inequality, land tenure, equity, community based forest management, power relation, Bangladesh

\section{Introduction}

In the recent global climate policy development, the Reducing Emissions from Deforestation and forest Degradation (REDD + ) program has emerged as one of the key promising mechanisms to both address the problem of emissions reduction and support the process of adaptation to climate change. The proponents of REDD+ focus on the synergies between a number of goals, such as environmental, financial, and social goals, and see the program as an effective, efficient, and equitable (the "three Es") mechanism to achieve all these goals (Duchelle et al., 2014; Nathan \& Pasgaard, 2017; Sunderlin et al., 2014; UN-REDD, 2011). However, it remains a debatable issue whether, to what extent, and most importantly how, REDD + can achieve its three Es. During the last decade, more than 300 sub-national REDD+ projects have been initiated in tropical developing countries at various levels and various scales (Sills et al., 2014; Sunderlin et al., 2014), and many more are ready to launch. The empirical trends show a mixed result, and an increasing number of scholars are more critical about the possibility of the expected outcomes (Agrawal, Chhatre, \& Hardin, 2008; Blom, Sunderland, \& Murdiyarso, 2010a; Hall, Hirsch, \& Li, 2011; Sikor et al., 2010).

The debates on this issue have two directions. In one direction, the debate focuses on the possible risks surrounding REDD+ policies, such as that national and local elites might dominate decision-making processes and capture the benefits, that the transfer of large sums of money could create a high risk of corruption (Hansen, Lund, \& Treue, 2009; Milne \& Adams, 2012), and the possibility of social equity (Blom, Sunderland, \& Murdiyarso, 2010b; Sikor et al., 2010). Some criticisms go further, questioning the neoliberal policy and its relations to the environment and social equity (Gezon et al., 1999; Newell \& Paterson, 2010; Peet, Robbins, \& Watts, 2010) and arguing that market-oriented policy instruments such as REDD+, and its efficiency framing, are taking an ever increasing prominence in environmental governance (Pascual, Muradian, Rodr' 'iguez, \& Duraiappah, 2010). In the other direction, the debate focuses on various kinds of challenges and possibilities related to the tradeoff among the three 
Es, such as the difficulties of mixing local priorities and interests with the global REDD+ objective, improved management of incentives within communities (Krause, Collen, \& Nicholas, 2013), improved institutional settings, adequate investment to improve administrative and technical capacity, and procedural clarity (Börner et al., 2010; Brockhaus, Di Gregorio, \& Mardiah, 2014; Lestrelin et al., 2013). Both directions of the debate show that there is a significant gap between the win-win promises of REDD+ and the reality, and we need a careful understanding about the interests of the marginalized communities in such process. Thus, one of the central questions for REDD+ is how we can ensure social justice and equity (Chomba, Kariuki, Lund, \& Sinclair, 2016; McDermott, Mahanty, \& Schreckenberg, 2013; Nathan \& Pasgaard, 2017), and there is an urgent call for further analysis to understand the relations between forest communities and REDD+.

Centering on the debate concerning relations between forest communities and REDD+, this study intends to contribute to the above critiques with an analysis of the interactions of power relations and institutional settings surrounding the community forest management (CFM) experience in Bangladesh. There is a wide variation in the meaning of the term CFM. In this study, we use CFM as a general term to include all forms of community-based forest management, including both co-managed forest and traditionally managed village common forest. CFM has been one of the prominent strategies in Bangladesh for more than two decades. However, inequalities and poor institutional capacity remain some of the key challenges (Koli, 2013,2015). Like many developing countries in Asia and Africa, ambiguous and insecure land tenure is also a trend in Bangladesh, especially in the Chittagong Hill Tracts (CHT) area. Like many of the REDD+ countries who are in the piloting and the readiness phase, Bangladesh has also recently initiated REDD + programs. At this early stage, a serious concern remains as to how the REDD+ initiatives can work properly on a pre-existing unequal situation among the people living near a forest (Brockhaus et al., 2014; Di Gregorio et al., 2013; Peskett, 2011), and how it can acknowledge the existing elements of inequality in enacting societal equity and safeguards (McDermott et al., 2013).

Based on qualitative case studies, this study aims to find out, first, how the existing CFM and other related institutional settings are shaping the distribution of forest access and benefits, and second, to what extent REDD+ can ensure the equitable benefits of the marginalized forest communities in Bangladesh. To understand the inequality aspects in depth, we focus on two different types of CFM regimes and forest community dynamics in Bangladesh. The first case study is the co-management of protected areas in the Chunoti Wildlife Sanctuary (CWS) in Chittagong, Bangladesh, where community members are directly participating in forest governance matters with other stakeholders and have institutionalized access to benefits and decision-making mechanisms. The second case study is focused on traditional village common forestry in the CHT region, where ethnic communities manages their village forests in a traditional manner with some support from NGOs and have experienced a long ethnic conflict and land tenure insecurity. Community members are excluded from any formal decision-making and benefit-sharing structure. Focusing on these two contrasting cases, this study explores the extent of the existing distributional inequality within the community members, and how contextual factors such as power relations and surrounding institutional settings are helping to perpetuate this kind of outcome.

The case study analysis finds that the distribution of various costs, benefits, and access to forest participation remain highly unequal among the different groups within the community. Unequal institutional access to forest decision making and to the land tenure security keep the marginalized communities either suppressed or influenced by the dominating group, especially in the ethnic conflict zone in the CHT forest area. This study argues that without ensuring the decision-making space for the marginalized groups, and without substantial changes towards the tenure complexity and mistrust surrounding ethnic conflicts, the emerging REDD+ initiatives in Bangladesh can strengthen the dominating group, which subsequently intensifies the vulnerability of the marginalized people. However, the present insecure and poor institutional conditions could be a driving force to bring about substantial changes in the equitable access and share of the marginalized communities. Bringing such changes requires long-term initiatives towards strengthening the capability of the marginal people, and their access to forest resources and decision making, which would also create a basis for a win-win outcome of REDD+. This paper is organized as follows. Following the introduction, Section 2 details the framework of the study. Based on the equity and power concepts, the framework employs a two-level analytical framework; distributional inequality, and underlying factors of such inequality, such as institutional settings and socio-political context. In Section 3, we describe the research method and the case study areas. In Section 4 we present our findings both from case studies and other sources of data. We present a discussion and conclusion in Sections 5 and 6 , respectively.

\section{Framework of the Study}

One of the key theoretical and policy issues in forest governance is the relationship between equality and governance outcome (Brockington, 2002; Leach, Mearns, \& Scoones, 1999). There are significant difficulties in 
generating measures of inequality that can capture its many different dimensions and their effect on resource governance outcomes (Prasad, Van Koppen, \& Strzepek, 2006). Some equity might be related to inequality at the distributional level or at the procedural level, which relate to a number of factors such as institutional settings, power relation, and the context of historical legacy. A number of authors focus on an equality framework. For example, McDermott et al. (2013) have developed a framework to analyze equity based on three-dimensional equity, such as contextual, procedural and distributive. Additionally, there are a number of studies framing equity in Payment of Ecosystem Services ( PES) in the recent literature (Chomba et al., 2016; McDermott et al., 2013; Nathan \& Pasgaard, 2017; Pascual et al., 2010). In our framework, we are broadly interested to examine the existing level of inequality from both its underlying contextual and power relation perspective. We focus on how the power relation, as an intricate part of the context, shapes inequality at various levels, and influences the capability of different individuals and groups, more specifically between marginalized and privileged groups. We also focus on how institutional initiatives interact within this unequal power relation context. In our framework, we first briefly explain the concept of equity and power, and then the key components of the analysis to understand CFM-REDD+ relations.

Equity is closely related to equality, yet the two concepts are distinguished in significant ways. Equity does not necessarily place emphasis on equality in terms of blanket uniformity, rather it is about levelling the conditions of social existence. Equity thus contrasts with the common notion of justice based on equal treatment for all, and emphasizes fairness and equal opportunities. In this notion of equal opportunity or equity perhaps can violate the formal principle of equality and freedom. Starting from the question of 'Equality of what?', Sen opposed all relative notions of equality, whether utilitarian equality or Rawlsian equality, and argued that ethical reasoning must be 'credible from the viewpoint of others' and propose 'basic capability equality' which can recognize the fundamental differences between human beings (Sen, 1979, 1992). In Sen's capability approach, individual advantage is judged by a person's 'capability to do things he or she has reason to value'. The concept of capability is therefore linked with the aspect of comprehensive opportunities and equity. Based on this notion of equity, in this study we analyze marginal people's opportunities to participate in forest decisions and how their capability is being shaped by the surrounding institutional settings and unequal power relation context.

Like equity, power is also a broad and contested concept. The discussion of power within the boundary of a community is reflected in Dahl's community power, and his definition of power as 'the ability to make somebody do something that otherwise he or she would not have done' (Dahl, 1957). This model of power focuses on the ability to influence decisions, however ignores those circumstances in which decisions are prevented from happening, i.e., the area of non-decision making (Bachrach and Baratz 1962). Bachrach and Baratz developed the "second face" of power, by which power is explained as the way decisions are made and the ability to prevent decision making and the process of exclusion of certain participants and issues altogether (Bachrach and Baratz 1962). Later, Lukes suggests the three-dimensional view to understand how power shapes participation pattern of the relatively powerless and how political systems prevent demands from becoming political issues (Dowding, 2006; Lukes, 2004, 2005). His "third face" of power focuses on the forms of controlling people's thoughts by the manipulation of their perceptions and preferences. The "third dimension of power" argues that powerful groups can prevent their potential opponents from understanding where their true interests lie by 'influencing, shaping or determining his very wants' (Lukes, 2005).

Based on Lukes' concept of power, this study conceptualizes power as multidimensional, which can explain both the participation and non-participation of community members, as well the context of the power relation. In our analysis, we employ the three faces of power concept, which helps to assess not only how the dominating group exercises its power though its advantages in political participation in forest governance, but also how powerlessness is shaped by this power relation. Thus, the important analytical factors in this framework include not only the observable participation, but also how certain groups are prevented from participating in the decision-making process, either through giving their passive consent to the dominated group or through their predominant ideas about their power relations.

\subsection{Key Components of Analysis}

Based on power concepts and equity, we developed our framework with three key analysis components: (1) the distributional level inequality, which places emphasis on the target of equity in terms of cost, risks, and benefits (McDermott et al., 2013); (2) the institutional development and settings that shape the access and entitlement of various groups of people and shape the equity; (3) power relations as a context that takes into account the 'ability to derive benefit from things' and the overall capability. 
In our analysis, we first focus on distributive equity, which here means the allocation or distribution of cost, benefit, and risk among different stakeholders in CFM. We are particularly interested to see what type of cost and risk the marginal forest communities are paying, and what type of benefit they are receiving in participating in the community-based conservation process. Secondly, we analyze the institutions which are shaping the access and entitlement of forest resources and decision making. A wide variety of institutions directly and indirectly shape the distribution of resources, benefit, and access. In this study, we analyze two types of institutional settings in particular: (1) the community based institution, and how it is shaping the access to the participation and decision-making role of the local community; and (2) land and forest tenure arrangement, and other institutional settings which are shaping the tenure security and other access to the forest. Finally, we focus on the socio-political context, such as the historical exclusion of the minority group from their resources, the continuation of dominance, the disparity among the Bengali majority and ethnic minority, and the marginalization of the poor community in general. Here, we will mostly focus on how this socio-political context, which is related to power relations in a complex way, is defining the ability of the marginalized forest communities to derive access to or benefit from the forest and forest management. We also focus on the extent to which institutional initiatives, such as the community-oriented conservation and development program, have shaped, or are shaped by, the political economic context and power relation.

\section{Methodology and Data Collection}

To understand the existing inequality and the future equity of the community members in the decision making, this study employs case study analysis. In this study, we are interested in assessing the existing element of inequality in the Chittagong and CHT forest areas, which are some of the key degraded areas and sties for REDD + . The CHT area is one of the most contested areas in Bangladesh in terms of tenure security, ethnic conflict, and other structural inequality. For our study we selected two different types of forest regimes: co-management-based protected area and traditional village common forest. The data of this study were collected from the case study through focus group discussion (FGD), in-depth interviews, direct observation, and from other sources, such as the report of the stakeholder consultation workshop and the report of 'Socioeconomic Baseline Survey of Chittagong Hill Tracts' by the United Nations Development Program (UNDP).

The empirical part of the case study is based on fieldwork conducted in the CWS, and two village common forests in the villages of Korangpara and Kaprupara in Banderban. The FGDs and in-depth interviews were conducted from August 2014 to August 2015. A total of 20 in-depth interviews and six FGDs (two in each village) were conducted. The total number of focus group members was 62 , and both female and male participants participated. In Korangpara and Kaprupara, which are ethnic communities, the FGDs and other interviews were conducted by local experienced person following our interview guidelines. The in-depth interviews were conducted with an open-ended questionnaire. In co-management type forest, respondents were Forest Department (FD) officials, NGO employees, local government representatives, forest users who are members of the co-management committee and council, and ordinary forest users. The questions were largely focused on the process of co-management initiatives and their involvement in such processes, how the forest user groups were formed and what type of changes they have experienced through their participation, and what type of difficulties and challenges they face while participating in the decision-making process of forest management. In Korangpara and Kaprupara, we conducted in-depth interviews with the village committee member, head kadbari (leader), ordinary member, and NGO representatives. Interview questions were targeted to land tenure situation, traditional forest management, their overall deprivation and relation with Bengali people, and trust towards existing systems. Participant observation was conducted several times during the period by walking the village forest, forest trails, different forestry plantations, and agroforestry fields. During each observation time, we had a discussion with village people in an informal manner to encourage them to express their genuine views, perception about the forest management, and other issues. The gathered information was recorded in field notes.

To support our above observation, we employ two reports. The first is a report on the stakeholder consultation workshop on 'Forests in the Chittagong Hill Tracts: Local Issues and Potential Approaches' held on 27 October 2011, organized by the UNDP. A total of 36 participants from three hill districts participated in the workshop. The participants were divided into four groups: group-1 - community people and traditional leaders headman, karbari; group-2 - elected leaders of the union and Upazilla Parishad (local government) chairman, members and the councilors from Hill District Councils; group-3-NGO representatives and lawyer; and group-4-government officials of the FD (UN-REDD (Dhaka), 2011. 'Forests in the Chittagong Hill Tracts: Local Issues and Potential Approaches' Bangladesh REDD+ Roadmap Process Background Information, Dhaka, Bangladesh (unpublished)). The second report is entitled 'Socioeconomic Baseline Survey of Chittagong Hill Tracts', conducted by the UNDP — Chittagong Hill Tracts Development Facility (CHTDF), published in 2009 (38). 


\subsection{Case Study Area: Chunoti Wildlife Sanctuary Co-Management-Based Protected Area}

Based on the co-management approach, the Nishorgo Support Project (NSP) was launched in 2003 as a mission of the Forest Department of Bangladesh, with financial and technical support from the United States Agency for International Development (USAID). At the initial stage, five protected areas were selected as pilot projects for five years. For this study, one of the pilot co-management project areas, the CWS, which is one of the most degraded and deforested protected areas in Bangladesh, was selected. The CWS covers seven reserved forest blocks of hill forests and is located in the southeastern region of Bangladesh (International Resource Group (IRG), 2006). The core and interface landscape of the CWS has a number of villages, other settlements, paddy land, and forest. The area is densely populated, and a majority of the population depends directly or indirectly on forest resources for their consumption and livelihood. There are 70 settlements (paras) with a total of approximately 7810 households located in and around the CWS (Mollah, A.R., M.M. Rahaman, 2004). The CWS has two geographical ranges: Chunoti and Jaldi. About $64 \%$ of the households are extremely poor, and the rest are either poor or middle class. On average, $40 \%$ of the households are landless, and in 30\% the members of the household are unemployed (Mollah, A.R., M.M. Rahaman, 2004). According to a study by Mollah et al. (2004), nearly three-quarters of the total population depend on the CWS for the collection of various primary forest products.

\subsection{Case Study Area of Korangpara and Kaprupara Village Common Forests}

In our study we focus on the CHT forest area, which is a contested area in terms of the forest rights, land tenure, and ethnic minority conflicts. The forest of CHT accounts for around $40 \%$ of the national forest coverage, and is the homeland of 11 minority indigenous groups in Bangladesh. In the CHT, land is administered by separate legal rules, which are based on customary rights and distinct from that of the rest of the country. Agriculture is the core economic activity of the indigenous people. In many places, the village common forest (VCF) is one of the traditional practices of managing forest by the communities in the CHT. These VCFs are basically very small woodland or forest, and range from an average of 20 to 120 hectares. Since the British colonial period, the ethnic groups in the CHT have been denied their traditional forest land access in the name of forest conservation. They are basically excluded from their customary rights on government-managed reserve forests, and are managing forests around their homesteads, which are known as VCFs. These are common property forest where the ethnic community traditionally manages their village forest; now, NGOs are engaged through some of their projects along with their traditional arrangement.

In our study, we selected two village forests in Banderban district: one located in Kornagpara village in Ruma Upazila, and another in Kaprupara in Lama Upazilla. All the population of the study area are from the Mro ethnic community, and belong to the Christian or Crama religions. The main livelihood in both of the villages is traditional agriculture. VCF is managed as a common property resource by the villagers. Generally, the village community manages the VCFs under the leadership of Mouza headmen. The management of these forests is based on a traditional resource management pattern. The members of the community were used to leading their life depending on natural resources with their traditional knowledge and customs. We did not have specific socio-economic data about these two villages; however, the overall CHT data represent their status, and show that farming/cultivation (plough) is the primary occupation of $18 \%$ of the total population. About three-quarters of the households (74\%) live below the lower poverty line, and $86 \%$ of households live below the upper poverty line. Almost all women in the CHT (94\%) live below the absolute poverty line, and about $85 \%$ live below the hardcore poverty line. Only $7.8 \%$ of CHT inhabitants completed primary education, and $2.4 \%$ completed secondary education. The average number of years of schooling for the CHT population is only 2.8 (38).

\section{Key Findings}

\subsection{The Contribution of the Local Community in Forest Protection}

The CWS was once one of the most deforested and degraded forest areas in Bangladesh. To understand the impact of CFM in forest protection, the study focused on what type of changes took place, particularly regarding plantations, fluctuations in animal and bird populations, and illegal felling. In both the FGD and the in-depth interview, the majority of the respondents expressed the opinion that this project brings positive results to forest health, such as reducing deforestation and forest degradation, along with enhanced biodiversity, and that they had actively been involved in bringing about this change. According to the opinion of the forest conserver and assistant forest conserver, forest coverage has increased significantly, especially due to the active participation of the local community, including poor and marginalized people. The forest users expressed that illegal logging and other means of extraction of natural resources still continue to some extent, however that they had decreased.

In VCFs in Kornagpara and Kaprupara in Banderban, the local community, the Mro ethnic group, are playing a significant role in conserving forests and water sources. They are actively maintaining tree cover with a diverse 
range of plants, such as medicinal plants, bamboo, wood trees, and fruit trees. The NGO representative informed us that the biodiversity in these VCFs is higher than that of any other forests. They also maintain animals and birds in their village forests, and preserve drinking water sources, streams, and other natural aquifers. The head kadbari of the VCF expressed that these forests are not only a source of their daily needs and livelihood, but that to them they have a deeper relation with nature. Traditionally, from their religious and cultural perspective, they respect forest, forest land and forest resources.

\subsection{Cost and Benefit of the Forest Communities}

One of the key discussions about protected area management is whether it genuinely benefits local forest-dependent communities. Through the FGDs and in the in-depth interviews in the CWS, we focused on what type of benefit the respondents received through the project period and what type of cost or constraint they faced. Some respondents in the focus group gave the opinion that this project had brought livelihood opportunities for local forest users, however the majority of the respondents expressed that the project had not brought many significant livelihood opportunities that they expected. In regard to the livelihood benefits, the respondents mentioned the formation of patrolling groups, and that these patrolling groups had received some grant money at one point. Many of the workers who were engaged in the illegal felling took the patrolling jobs, which brought about a positive change. Some of the alternative livelihood benefits that the respondents mentioned included training program and grant money awarded for income-generating activities such as poultry, nursery building, vegetable garden planting, etc. In the in-depth interviews, one woman told us that quite a large number of forest-dependent communities used to live in the protected areas engaging in the unsustainable extraction of forest resources. They used to produce battle leaf and collect wood and sangrass from the forest for their livelihood and for their daily use. Some of them were engaged in illegal felling and the illegal extraction of forest resources, mostly as workers. With the declaration of the protected areas, these opportunities began to shrink, and many of the forest users faced livelihood difficulties. 'The project initially gave us assurances of providing livelihood supports but they failed to keep their promise', mentioned another forest user. One FD officer, the assistant forest conserver, also informed us that assurances had been made of generating alternative livelihoods instead of unsustainable extraction from the project, but that in reality many of them remained mere rhetoric. The initiatives to improve the non-timber forest products (NTFPs) market for the local forest users also remain in a poor condition.

In the VCFs, the cost, benefit, and risk issues are different from the co-managed protected areas. The arrangement for the ethnic people for obtaining access to forest resources and benefit is quite different from other arrangement. In the interview, the member of the Mro ethnic community expressed that, outside of this small village forest, they did not have any access to the government forest, such that their forest benefits are basically at the substantial level use of their VCF resources. They also informed us that they experienced fear and lack of trust regarding the government's intention about the inclusion of their forest into the reserve forest or protected areas, as they might be further displaced from their land and forest resources. In the workshop on CHT consultation, the government official expressed that participatory community forestry is not functioning well in the CHT context due a lack of coordination among key stakeholders. They felt there was a need to initiate a negotiation process with the FD and with other relevant stakeholders to minimize misunderstanding and mistrust.

\subsection{Institutional Settings}

A wide variety of institutions, both formal and informal, are related to the issue of the equity of the community members. In this study, we analyze two specific types of intuitional settings that are directly related to the capability of the marginalized community. First, we analyze the CFM institutions to explore to what extent they are creating the institutional opportunity to obtain access to forest resources and forest decision making. Second, we analyze the surrounding institutional settings which are defining their basic rights to forest resources and their capability to respond to unequal power relation in the socio-political context.

\subsubsection{Access to Participation and Decision-Making Space in CFM Institutions}

In the co-management approach, the co-management council and co-management committee were designed as two-tier management bodies which are comprised of representatives from civil society groups, local administrators, people from local villages, and representatives of various government organizations. The Government of Bangladesh has published a specific distribution of membership for both the co-management committee and council. The council has around 50 members, who are from different communities covering the total landscape. The council is responsible for planning, management, and decision-making in the CWS, including the setting and reviewing of annual plans, the resolution of conflicts among stakeholders, the design of policies, and ensuring the fair distribution of benefits derived from the forest and co-management activities. The committee, on the other hand, is the operational body responsible for the implementation of the decisions and plans approved by the 
council $^{(39)}$. There are about 20 committee members, who are elected by the council following structured guidelines. The committee is responsible for ensuring the sharing of forest benefits, such as benefits from eco-tourism, and for implementing alternative income generation for sustainable livelihoods and enhancing the skills of local stakeholders. From the FGDs and interviews, we found that the distribution of respondents from co-management institution according to their income and other societal status was highly disproportional; the majority of the committee and council members belonged to the relatively rich and elite groups in the community, while only a few members were from the poor group.

In the key informant interview, one respondent expressed that in most of the cases, the members who already have a position and command in the society take the leading role on behalf of the ordinary people. 'We have some opportunities to participate, we go to the committee and meeting, but ultimately our opinion does not work,' informed one co-management committee member from the ordinary group. In most of the cases, individuals who were already in a decision-making role, such as the FD officials or project officials, and were able to influence the discussions and decisions, were least influential in any decision making. From the FGDs, we found that the female forest users remained highly invisible regarding their access to decision-making, despite the fact that they were very active in forest conservation. All female representatives in both the co-management committee and the council were from the local government and represent the local elite class, and they usually participated in one kind of token basis. None of the female representatives came from the marginalized forest-user group. According to interviews with committee members and FD officials, the marginalized or poor forest users were not sufficiently capable of taking such responsibilities. They were not well educated, and ignorant regarding decision-making and other important jobs. They also agreed that there are no capacity-building initiatives for them. The in-depth interview with other committee and council members in the group also reflected a similar type of expression.

Unlike the co-management initiatives in the CWS, VCF is not authorized by any government act, but rather their rich tradition of resource management. In the VCF, there is a VCF committee, which represents all the households in the committee. Both the head member and the ordinary members informed us in the interview that their organization is ruled by its customary rules, where they have a general body formed by each household member, and there is an executive body consisting of a village headman, a secretary, and a treasurer. They also informed us that there is an election every three years or so, when they form a new VCF committee. They have no written rules, however they have good trust in their governance system and more or less follow their rules. From the FGD we found that the general committee member collectively sets the rules of the VCF, such as what would happen if there were a break of the rules. They also decided what type of benefit they can receive from the forest, and what type of works or benefit would not be allowed; for example, members are allowed to harvest bamboo for their household with permission, however if somebody uses wood for a commercial purpose without permission they have to pay a fine. The organization also has common funds, which they usually use for common benefits such as education, health, and social and religious activities. In general, they traditionally following their rules and maintain their forest and related common resources.

\subsubsection{Land Ownership and Tenure Security Settings}

In the CHT area, land tenure and ownership issues are the most contested issues. The land ownership patterns and their transaction patterns are different from other parts of Bangladesh, and the nature of conflict also different. The forest communities in the CHT have been suffering from land tenure insecurity over the past two centuries. Different state policy changes in different administrative periods, such as the British period, Pakistan period, and Bangladesh period, created tenure insecurity for the marginalized ethnic community in the hill tract forest (Arens \& Chakma 2002). The conflict regarding land ownership is particularly acute due to the construction of Kaptati Dam, a hydroelectric power plant, on the Karnaphuli River in the early 1960s. The power plant inundated about $40 \%$ of the CHT's land and displaced about 100,000 indigenous people; the majority had no land title and were neither resettled nor paid compensation. To combat the independence movement of the indigenous peoples in the CHT from 1976 onward, the reaction of the Bangladesh Government was to initiate militarization and flood the area with landless Bengali people from the plains (Arens \& Chakma 2002). About 200,000 lowland people were resettled under this scheme of government-owned khas, or fallow land, which was actually community land that had been used by indigenous people for generations (Barua 2001). Consequently, many indigenous people were displaced again from their community land, as very few had ever secured land. Our FGD discussions and interviews with the Mro community also revealed contested land ownership between the ethnic and Bengali settler households, and various kinds of land-grabbing and domination. Some of them had to relocate for various kinds of conflicting situations. Losing their land is not a usual occurrence. They informed us that many of their properties have no registered ownership, and that it is thus difficult to claim from official authority. The baseline survey 
report of the UNDP-CHTDE in 2009 showed the status of various factors related to the land tenure insecurity in CHT. Table 1 shows the comparative status of the Bengali and indigenous community on this issue.

Table 1. The status of land tenure insecurity in CHT

\begin{tabular}{|c|c|c|}
\hline Land Tenure Related Factors & Indigenous Communities & Bengali (Majority) Community \\
\hline Traditional customary property & $\begin{array}{l}55 \% \text { land traditional customary } \\
\text { property }\end{array}$ & - \\
\hline Registered ownership & $21 \%$ of land & $52 \%$ of land \\
\hline \multirow{3}{*}{ Migration } & $\begin{array}{l}38 \% \text { had to shift from their places } \\
\text { (forced migration) }\end{array}$ & \multirow{3}{*}{$\begin{array}{l}62 \% \text { of the Bengali populations are } \\
\text { living in rural CHT for less than } 30 \\
\text { years (transmigrated) }\end{array}$} \\
\hline & $\begin{array}{l}\text { An average indigenous household } \\
\text { had to change its permanent } \\
\text { address almost two times }\end{array}$ & \\
\hline & $\begin{array}{l}20 \% \text { were displaced more than } \\
\text { once }\end{array}$ & \\
\hline Land dispossession & $\begin{array}{l}22 \% \text { reported incidence of land } \\
\text { dispossession }\end{array}$ & - \\
\hline $\begin{array}{l}\text { Conflict and Violence Scenario } \\
\text { (households which faced armed } \\
\text { violence before the CHT treaty) }\end{array}$ & $25 \%$ & Around 10\% \\
\hline $\begin{array}{l}\text { Subjective feelings about the } \\
\text { relationship between Bengali and } \\
\text { indigenous communities }\end{array}$ & $\begin{array}{l}\text { The majority of the indigenous } \\
\text { people report that the relationship } \\
\text { is 'not friendly' and 'hostile' }\end{array}$ & $\begin{array}{l}\text { The majority of the Bengali reports } \\
\text { that the relationship is 'friendly' } \\
\text { and 'almost friendly' }\end{array}$ \\
\hline
\end{tabular}

Source: Based on the UNDP-CHTDE report on 'Socioeconomic Baseline Survey of Chittagong Hill Tracts' in 2009.

The land tenure situation in the CWS is not the same as in CHT, however neither is it secure enough. According to interviews with the FD officers and the civil society organization personnel, a number of settlements and paddy lands can be found all around the CWS due to encroachments on forest land. They expressed that the local elite had actually encroached or taken control of lands, and that the majority of people in the area had been left poor and almost landless. There is a plan to distribute some of the khas lands (government land) to distribute social forestry benefits within the community forest users, and around 120 hectares of land on the buffer zone of the protected areas has been distributed to 240 local forest users. However, according to the opinion of the marginalized forest user groups, the large portion of the land distribution went to the local elites, as they have good connections with the management authority and already have possession of governmental land.

\subsubsection{Other Institutional Settings of the Socio-Political Context}

After a long conflict, the Peace Accord of CHT in 1997 was considered to bring a peaceful settlement of the ethnic people. The Accord was committed to provide two important safeguards: first, devolution of land administration to the hill councils, without whose comments no land are to be settled, leased out, transferred, or compulsorily acquired (section 64, Hill District Council Act, 2000); and second, the resolution of land-related disputes by a Commission on Land (Ahsan, 2012). The village forest people expressed that the marginalization of the ethnic group is continuing in the CHT and in the VCF areas. The FGD respondents were not optimistic about peace and justice in their area. Some of them were not well aware about the Peace Accord of CHT and related negotiations. The participants of the stakeholder consultation workshop on CHT spoke of the weak implementation of the Peace Accord of CHT and related institutions. Regarding the CHT situation and its relation to future REDD+ initiatives, the participants investigated various institutional weakness and the cause behind them. Table 2 shows the perceptions of the stakeholder workshop participants about various institutions, and their present status on CHT forest related issues. 
Table 2. Present status of various institutions regarding future REDD+ relations in CHT

\begin{tabular}{|c|c|c|}
\hline Institutional Settings & Existing Status & Perception about the Cause \\
\hline CHT Accord & $\begin{array}{l}\text { Partially functional, not } \\
\text { properly implemented }\end{array}$ & $\begin{array}{l}\text {-Lack of political will of government } \\
\text {-Lack of initiatives to respond to fear and } \\
\text { mistrust surrounding CHT Accord }\end{array}$ \\
\hline $\begin{array}{l}\text { Hill District } \\
\text { Council }\end{array}$ & Not functioning & $\begin{array}{l}\text { The forest and land department is not } \\
\text { transferred to Hill District Council } \\
\text { Lack of democratic practice and } \\
\text { accountability }\end{array}$ \\
\hline $\begin{array}{l}\text { Coordinated } \\
\text { development activities among Regional } \\
\text { Council, Hill District Council and } \\
\text { Ministry of CHT Affairs }\end{array}$ & Partially functional & $\begin{array}{l}\text { Coordination gap and lack of } \\
\text { governmental will } \\
\text {-Lack of proper implementation of CHT } \\
\text { Accord }\end{array}$ \\
\hline $\begin{array}{l}\text { Forest and Wildlife } \\
\text { Protection Act }\end{array}$ & Partially functional & $\begin{array}{l}\text { Conflict with customary law and absence } \\
\text { of consultation with local community }\end{array}$ \\
\hline Customary laws & $\begin{array}{l}\text { In some places it is } \\
\text { effective. } \\
\text { Partially functional }\end{array}$ & $\begin{array}{l}\text {-Conflict between customary law and } \\
\text { state law } \\
\text {-Lack of accountability of relevant } \\
\text { stakeholders } \\
\text {-Lack of capacity development initiatives } \\
\text { for the headmen }\end{array}$ \\
\hline $\begin{array}{l}\text { Participatory } \\
\text { Community Forestry }\end{array}$ & $\begin{array}{l}\text { Not functioning well in } \\
\text { CHT context } \\
\text { Village Common Forest } \\
\text { is not recognized } \\
\text { properly }\end{array}$ & $\begin{array}{l}\text { Lack of coordination among the key } \\
\text { stakeholders } \\
\text {-Lack of awareness } \\
\text {-Misunderstanding and mistrust between } \\
\text { Forest Department and other relevant } \\
\text { stakeholders }\end{array}$ \\
\hline $\begin{array}{l}\text { Initiatives towards education for all and } \\
\text { skilled manpower }\end{array}$ & Not functioning well & $\begin{array}{l}\text { Reluctance of the government on this } \\
\text { issue }\end{array}$ \\
\hline
\end{tabular}

Source: Based on the report of stakeholder consultation workshop on CHT and future REDD+ in 2011.

The in-depth interview with the NGO officer similarly revealed their opinion that the treaty was not implemented properly due to a lack of political will and honesty of the Bangladesh government. In our interview, the Mro community members expressed that there was a lack of trust between the government and the indigenous community. They did not feel assured about any commitment of the government or related organizations. Regarding their feeling and trust towards the Bengali community, they were divided; some of them expressed that the relationship with the Bengalis was not warm enough.

\section{Discussion}

The experiences of CFM in both the co-management and village common type forests reveal several key factors, which shows the nature of the existing inequality and the future possibilities of CFM-REDD + relations. This study demonstrated that community members in both of the forest areas have contributed to forest conservation and the improvement of biodiversity. However, despite their contribution to improve forest conservation, forest communities have received limited forest benefits, especially the poor and marginalized forest communities. The case study on the co-management of the protected area informed us that the poorest people, who are most dependent on the forest resources for their livelihood and daily substances, are suffering most. There is a gap between the promised livelihood benefits assured by the co-management project and the actual benefits received. The marginalized groups felt that they had basically been left out of these benefits. Nevertheless, the co-management brought authorized political and decision-making space for the community people, where along 
with government and other stakeholder they can participate in decision making. The case study also revealed that the decision-making access and the role of the community people are not equal in terms of intra-group level. The rich and local elite is playing the key role in such kinds of participation, and poor people are participating in a passive way and following basically what the elite groups decide. In the VCF cases, we found that within their small community forest area, they are receiving forest benefit and participating in the forest management in a traditional but democratic way. However, they are out of the benefit sharing mechanism of the government and the involvement of the broader forest governance process. Their access to forest resources and forest decision-making remain highly unequal compared with the Bengali majority people, and they even lack recognition about their contribution to forest management. Both types forest management show that the marginal groups in the community remain either out of the access to forest decisions or are obtaining access in a limited and passive way. We found that even in formal institutional settings marginal people's rights and access to the forest have not been actualized. Crucial questions remain about the capability of the marginalized group, and whether they really can intervene in the existing unequal situation. There are several key factors which could explain why the CFM initiatives remain far from bringing equity to these marginal people.

First, the local institutional initiatives to ensure decision-making space for the community people, particularly the marginalized people, remain poor. Even in the co-management based conservation initiatives, we found that their role in decision-making is not influenced. The level of community participation in this co-management arrangement can be referred to as 'tokenism', which allows them to hear and have a voice while lacking the power to ensure that their views are properly discussed (Arnstein, 1969; Carlsson \& Berkes, 2005). Other studies also found similar rhetorical authority and autonomy of the community people (Agarwal, 2001; Cornwall, 2003; Mohanty, 2004). In the CHT, the situation is more complex and there is no significant institutional development, which helps the ethnic community to include their participation in a proper benefit sharing mechanism. Fear and mistrust among the ethnic minority indicates that the inclusion process may cause further marginalization of their access and control over forest resources, which is also reflected in some other studies (Ahsan, 2012; Rasul, 2007; Zahed, 2013). Within the VCF, ethnic people are maintaining their benefit and other management well, however in terms of their access and bargaining capacity with the other stakeholders they remain extremely suppressed. Some NGOs are working with the ethnic people, but all of these initiatives are inadequate, especially to bargain on their own behalf with the majority Bengali people and government institutions.

Second, we can say that tenure security and ensuring other rights of the marginalized forest communities remain decisive factors for the future success of REDD+. The co-management arrangement has brought some change in forest governance by including local people in the forest governance process; however, it did not yet bring enough clarity in land rights, land tenure, or forest rights matters. In the CHT forest, the situation is much worse and more complicated. Land ownership and land tenure remain two of the most conflicting and challenging issues in the CHT forest, and there has been basically no visible change in the situation. This study shows how the ethnic people are continuously suppressed by the broader dominant power structure in the society due to their land tenure insecurity. A number of studies have shown how most past forest policies overlooked the benefit and interests of the ethnic community (Khan, 1998; Koli, 2013; Rasul, 2007).

Third, the power relations within the society have not been considered seriously in past CFM-related initiatives. In the CWS, we found the co-management initiative could not break the deep-rooted socio-political context of the domination of the elite in the society. We found that, even though the marginalized communities are officially authorized to participate, their participation remains silent or passive in considering the future risk of going against the local elites. In the CHT forest area, the community members remain suppressed and passive, and are trying to maintain the status quo considering all the risk factors. In this setting, the dominant power relations, either as local elite or majority identity group sustaining their power not only assuring their lion's share, but also controlling various contextual factors to suppress the others. There is a lack of systematic institutional support to empower the marginal community on a long-term basis, where they can participate in a real sense, not only in terms of token participation, and can also break the dominant influence and manipulation. The initiatives fail to recognize the fundamental differences between the already privileged group and the deprived group; thus, the concerns of equity remain weak.

Lukes' three-dimensional view of power helps to explain how the powerful group sustains its control on forest resources and forest decision making. The inequality at various levels continues to exist not only because the powerful group have higher capability, for example higher bargaining capacity, but also due to the weak capability of the marginal group to respond to such domination. The case study shows that the level of participation in the forest decision-making depends not only the opportunity they may have, but also whether and how they can utilize that opportunity. In the co-management committee, despite having a similar type of access and opportunity to 
participate, marginal people could not turn their opportunity into a meaningful engagement. Thus, without considering the powerlessness of the marginalized people very seriously, any kind of initiative would remain superficial. Without taking substantial institutional development into account in CFM-REDD+ relations-which can ensure not only access and decision-making entitlement but also create the capability and empowerment of the marginalized people in the long term - any superficial initiative can exacerbate the situation.

\section{Conclusions}

The idea of REDD+ initiatives and related opportunities for forest communities is simple. The most challenging and significant questions in this arrangement are who has the rights to land, trees, and carbon payment. The underlying question is, what would the outcome be if REDD+ proceeded before the tenure situation was clarified, or before the placement of new arrangements of channeling benefits to local people? One answer is that in the future, both REDD+ and the forest communities might be undermined in a number of ways. It is evident that developing countries all around the globe are facing challenges related to land rights and resource rights. Experiences of CFM in Bangladesh have shown that, as the value of standing forests or forest land increases, powerful actors tend to capture the winnings to the detriment of the less powerful forest-dependent poor. If REDD+ increases in value it may also increase conflicts, as claimants stand to gain more by winning control (Cotula \& Mayers, 2009). However, in recent decades the changes in forest governance from state-centric to people-centric, though somewhat limited and partial, have been an attempt to recognize the tenure rights of forest peoples. Still, in this devolution of forest governance initiatives, poor and weak downward accountability and institutional capacity, along with the dominance of local elites, remain key features. The devolved forest rights are also limited to management. Management rights do not extend to land. While forest products belong to the village community, ownership of the tress and of the land usually remains with the state, which may unilaterally terminate the management agreement and may reallocate rights over to third parties. This seriously undermines the security of local rights under CFM arrangements (Cotula \& Mayers, 2009). This is particularly important for the CHT forest areas. The less powerful group, such as indigenous or other marginalized groups, often loses out, especially when there is a history of conflicts over resources and land rights. With the present land tenure situation, there are always high possibilities to enhance further marginalization of the poor forest communities in Bangladesh and around the globe, especially ethnic forest communities that have a long history of exclusion and marginalization.

Therefore, the debate and discussion should continue as how best to achieve this, and how to face some of the key challenges such as inequalities, poor institutional capacity, insecure land tenure, etc. If the tenure security problem can be secured as well as instigating a stronger bargaining capacity of marginalized communities in local forest management, then the future REDD+ can bring more benefits all round. Bangladesh is one of the countries that is most vulnerable to climate change. The CFM can be a credible platform for forest management, assisting adaptation, and poverty reduction. REDD + should emphasize rewarding not only the reduction of deforestation and forest degradation, but also conservation and sustainable forest management in a more comprehensive way. The present devolution of forest management through the CFM strategy is a relatively new phenomenon in Bangladesh, and offers wider possibilities of positive growth. In the context of climate change, which is extremely complicated and involves various aspects, any initiatives should be based on a long-term and sustainable approach. The present insecure land tenure situation, poor institutional capacity of the local forest management institutions, and the socio-political conflicts of local elites vs. marginalized forest communities, could be driving forces for changing the whole scenario. The initiatives for transferring central control of forest management to local institutions should be further extended, establishing an effective local CFM institution. The CFM should be an integral part not only of the forest management process, but also of the forest governance mechanism. The appropriate and proportionate presence of marginalized forest communities in the local forest management institution would ensure their benefits, and potentially substantially contribute to forest governance. Resource and access capture by local elites, which is a very common phenomenon in agrarian societies such as Bangladesh, can eventually be reduced through strengthening the capability of the marginalized forest communities in all spheres of forest governance, which would gradually enhance policy reform. The inclusion of broader local forest communities in forest governance and the secure tenure of land and forest resources would not only ensure the benefits of the forest communities, but would also ensure their sustained commitment towards REDD+.

Acknowledgments: The authors thank the villagers of Chunoti Wildlife Sanctuary, Kornagpara and Kaprupara Bangladesh for their support during the field survey. They also thank to the support of the NGO "Arannayk Foundation' for conducting the interviews in the ethnic communities in Banderbans. 


\section{References}

Agarwal, B. (2001). Participatory Exclusions, Community Forestry, and Gender: An Analysis for South Asia and a Conceptual Framework: Erratum. World Development, 29(12), 1623-1648. https://doi.org/10.1016/S0305-750X(01)00066-3

Agrawal, A., Chhatre, A., \& Hardin, R. (2008). Changing governance of the world's forests. Science, 320(5882), 1460-1462. https://doi.org/10.1126/science.1155369

Ahsan, M. (2012). Conflicting Issues and Challenges Related to Common Property Management and Customary Rights of the Indigenous People of Chittagong Hill Tracts in Bangladesh. Ssrn, 2011(September), 1-39. https://doi.org/10.2139/ssrn.2004106

Arens, J., \& Chakma, K. N. (2002). Bangladesh: Indigenous Struggle in the Chittagong Hill Tracts. In M. Mekenkamp, P. van Tongeren, \& H. van de Veen (Eds.), Searching for peace in Central and South Asia: an overview of conflict prevention and peace building activities. London, UK: Lynne Rienner Publishers.

Arnstein, S. R. (1969). A ladder of participation. Young. https://doi.org/10.1080/01944366908977225

Barua, B. P. (2001). Ethnicity and National Integration in Bangladesh: A study of the Chittagong Hill Tracts. New Delhi, India: Har-anand Publications Ltd.

Blom, B., Sunderland, T., \& Murdiyarso, D. (2010a). Getting REDD to work locally: lessons learned from integrated conservation and development projects. Environmental Science and Policy, 13(2), 164-172. https://doi.org/10.1016/j.envsci.2010.01.002

Blom, B., Sunderland, T., \& Murdiyarso, D. (2010b). Getting REDD to work locally: lessons learned from integrated conservation and development projects. Environmental Science \& Policy, 13(2), 164-172.

Börner, J., Wunder, S., Wertz-Kanounnikoff, S., Tito, M. R., Pereira, L., \& Nascimento, N. (2010). Direct conservation payments in the Brazilian Amazon: Scope and equity implications. Ecological Economics, 69(6), 1272-1282.

Brockhaus, M., Di Gregorio, M., \& Mardiah, S. (2014). Governing the design of national REDD +: An analysis of the power of agency. Forest Policy and Economics, 49, $23-33$. https://doi.org/10.1016/j.forpol.2013.07.003

Brockington, D. (2002). Fortress conservation: the preservation of the Mkomazi Game Reserve, Tanzania. Indiana University Press.

Carlsson, L., \& Berkes, F. (2005). Co-management: Concepts and methodological implications. Journal of Environmental Management, 75(1), 65-76. https://doi.org/10.1016/j.jenvman.2004.11.008

Chomba, S., Kariuki, J., Lund, J. F., \& Sinclair, F. (2016). Roots of inequity: How the implementation of REDD+ reinforces past injustices. Land Use Policy, 50, $202-213$. https://doi.org/10.1016/j.landusepol.2015.09.021

Cornwall, A. (2003). Whose voices? Whose choices? Reflections on gender and participatory development. World Development, 31(8), 1325-1342. https://doi.org/10.1016/S0305-750X(03)00086-X

Cotula, L., \& Mayers, J. (2009). Tenure in REDD: Start-point or afterthought? IIED.

Dahl, R. A. (1957). The concept of power. Systems Research and Behavioral Science, 2(3), 201-215.

UNDP-CHTDF Dhaka. (2009). Socio-Economic Baseline Survey of Chittagong Hill Tracts. UNDP Dhaka: Dhaka, Bangladesh.

Di Gregorio, M., Brockhaus, M., Cronin, T., Muharrom, E., Santoso, L., Mardiah, S., \& Büdenbender, M. (2013). Equity and REDD+ in the media: a comparative analysis of policy discourses. Ecology and Society, 18(2).

Dowding, K. (2006). Three-dimensional power: A discussion of Steven Lukes' power: A radical view. Political Studies Review. https://doi.org/10.1111/j.1478-9299.2006.000100.x

Duchelle, A. E. et al. (2014). Linking forest tenure reform, environmental compliance, and incentives: lessons from REDD+ initiatives in the Brazilian Amazon. World Development, 55, 53-67.

Gezon, L. L., Paulson, S., Livermann, D., Moran, E. F., Rindfuss, R. R., Stern, P. C., ... Watts, M. (1999). Politics, Ecologies, Genealogies.

Hall, D., Hirsch, P., \& Li, T. M. (2011). Introduction to powers of exclusion: land dilemmas in Southeast Asia.

Hansen, C. P., Lund, J. F., \& Treue, T. (2009). Neither fast, nor easy: the prospect of Reduced Emissions from 
Deforestation and Degradation (REDD) in Ghana. International Forestry Review, 11(4), 439-455.

International Resource Group (IRG). (2006). Management Plans for Chunoti Wildlife Sanctuary.

Khan, N. A. (1998). Land tenurial dynamics and participatory forestry management in Bangladesh. Public $\begin{array}{llll}\text { Administration } \quad \text { and } & \text { 18(4), 335-347. }\end{array}$ https://doi.org/10.1002/(SICI)1099-162X(1998100)18:4<335::AID-PAD21>3.0.CO;2-F

Koli, A. (2013). Community forest management addressing social vulnerability of forest communities in Bangladesh. International Forestry Review, 15(3). https://doi.org/10.1505/146554813807700100

Koli, A. (2015). Understanding environmental civil society activism in bangladesh. Civil Society in Asia: In Search of Democracy and Development in Bangladesh.

Krause, T., Collen, W., \& Nicholas, K. A. (2013). Evaluating safeguards in a conservation incentive program: participation, consent, and benefit sharing in indigenous communities of the Ecuadorian Amazon. Ecology and Society, 18(4).

Leach, M., Mearns, R., \& Scoones, I. (1999). Environmental entitlements: Dynamics and institutions in community-based natural resource management. World Development, 27(2), 225-247. https://doi.org/10.1016/S0305-750X(98)00141-7

Lestrelin, G., Trockenbrodt, M., Phanvilay, K., Thongmanivong, S., Vongvisouk, T., Thuy, P. T., \& Castella, J.-C. (2013). The context of REDD + in the Lao People's Democratic Republic: Drivers, agents and institutions (Vol. 92). CIFOR.

Lukes, S. (2004). Three-Dimensional Power. In Power. A Radical View (2nd ed., pp. 108-151). https://doi.org/10.1037/023990

Lukes, S. (2005). Power. A Radical View. (1974). Basingstoke and New York: Palgrave MacMillan.

McDermott, M., Mahanty, S., \& Schreckenberg, K. (2013). Examining equity: a multidimensional framework for assessing equity in payments for ecosystem services. Environmental Science \& Policy, 33, 416-427.

Milne, S., \& Adams, B. (2012). Market Masquerades: uncovering the politics of community-level payments for environmental services in Cambodia. Development and Change, 43(1), 133-158.

Mohanty, R. (2004). Institutional dynamics and participatory spaces: The making and unmaking of participation in local forest management in India. IDS Bulletin, 35(2), 26-32. https://doi.org/10.1111/j.1759-5436.2004.tb00118.x

Mollah, A. R., Rahaman, M. M., \& M. S. R. (2004). Site-level field appraisal for protected area co-management: Teknaf Game Reserve. Nature Conservation Management (NACOM). Dhaka.

Nathan, I., \& Pasgaard, M. (2017). Is REDD + effective, efficient, and equitable? Learning from a REDD+ project in Northern Cambodia. Geoforum, 83(February), 26-38. https://doi.org/10.1016/j.geoforum.2017.04.020

Newell, P., \& Paterson, M. (2010). Climate Capitalism. Climate Capitalism: Global Warming and the Transformation of the Global Economy. https://doi.org/10.1080/09644016.2011.589588

Pascual, U., Muradian, R., Rodr|'|iguez, L. C., \& Duraiappah, A. (2010). Exploring the links between equity and efficiency in payments for environmental services: a conceptual approach. Ecological Economics, 69(6), 1237-1244.

Peet, R., Robbins, P., \& Watts, M. (2010). Global political ecology. Routledge.

Peskett, L. (2011). Benefit sharing in REDD+: exploring the implications for poor and vulnerable people. World Bank and REDD-Net, 244362--1232059926563.

Prasad, K. C., Van Koppen, B., \& Strzepek, K. (2006). Equity and productivity assessments in the Olifants River basin, South Africa. In Natural resources forum (Vol. 30, pp. 63-75).

Rasul, G. (2007). Political ecology of the degradation of forest commons in the Chittagong Hill Tracts of Bangladesh. Environmental Conservation, 34(2), 153-163. https://doi.org/10.1017/S0376892907003888

Sen, A. (1979). Equality of what? Tanner Lectures on Human Values, 1, 195-220. https://doi.org/10.1093/0198289286.003.0002

Sen, A. (1992). Inequality reexamined. Clarendon Press.

Sikor, T., Stahl, J., Enters, T., Ribot, J. C., Singh, N., Sunderlin, W. D., \& Wollenberg, L. (2010). REDD-plus, 
forest people's rights and nested climate governance. Elsevier.

Sills, E. O., Atmadja, S. S., de Sassi, C., Duchelle, A. E., Kweka, D. L., Resosudarmo, I. A. P., \& Sunderlin, W. D. (2014). REDD+ on the ground: A case book of subnational initiatives across the globe. CIFOR.

Sunderlin, W. D., Larson, A. M., Duchelle, A. E., Resosudarmo, I. A. P., Huynh, T. B., Awono, A., \& Dokken, T. (2014). How are REDD+ proponents addressing tenure problems? Evidence from Brazil, Cameroon, Tanzania, Indonesia, and Vietnam. World Development, 55, 37-52.

UN-REDD. (2011). The UN-REDD Programme Strategy 2011--2015. UN-REDD Geneva, Switzerland.

Zahed, I. U. M. (2013). Conflict between government and the indigenous people of Chittagong Hill Tracts in Bangladesh. IOSR Journal of Humanities and Social Science, 16(5), 97-102. Retrieved from http://iosrjournals.org/iosr-jhss/papers/Vol16-issue5/O01658691.pdf

\section{Copyrights}

Copyright for this article is retained by the author(s), with first publication rights granted to the journal.

This is an open-access article distributed under the terms and conditions of the Creative Commons Attribution license (http://creativecommons.org/licenses/by/4.0/). 